\title{
Post-accession Polish migrants-their experiences of living in 'low-demand' social housing areas in Glasgow
}

\author{
Derek McGhee \\ Department of Sociology and Social Policy and the ESRC Centre for Population Change ${ }^{\dagger}$, \\ Social Sciences, University of Southampton, Southampton SO17 1BJ, England; \\ e-mail: D.P.McGhee@soton.ac.uk
}

Sue Heath

Department of Sociology and the Morgan Centre, School of Social Sciences, Manchester University, Manchester M13 9PL, England; e-mail: Sue.Heath@Manchester.ac.uk

Paulina Trevena

ESRC Centre for Population Change, Social Sciences, University of Southampton, Southampton SO17 1BJ, England; e-mail: Trevena@soton.ac.uk Received 30 March 2012; in revised form 14 May 2012

\begin{abstract}
Glasgow is a city well known for bringing together a 'housing need' with a 'housing supply'. Post-accession Poles are the most recent population to fill the 'void' in Glasgow's 'unpopular' and therefore low-demand housing in areas of social deprivation. In this paper we will focus on the intersection of individual paths with institutional projects occurring at specific temporal and spatial locations: through examining the housingseeking activities of migrants and the low-demand accommodation letting activities of, for example, the Glasgow Housing Association. In the paper we examine the meanings, processes, experiences, and perceived advantages (for migrant families and for housing associations) and also the disadvantages associated with post-accession Polish families taking up and being potentially 'steered' into tenancies in particular areas of Glasgow.
\end{abstract}

Keywords: Poland, European migrants, post-accession, social housing, Glasgow, housing associations

\section{Introduction}

The EU enlargement of 2004 was a highly consequential one for the United Kingdom. The opening of the UK labour market to nationals of accession eight (A8) countries resulted in one of the largest and most intensive migration flows in contemporary European history. Previous published research has stated that this flow of migrants from A8 states has been described as "one of the most important social and economic phenomena shaping the UK today" (Pollard et al, 2008, page 7). Notably, the overwhelming majority of the new migrants had arrived from Poland (Home Office, 2009). The Polish community thus appears to be the fastest growing migrant community in present-day Britain, with Poles having become the single largest foreign national group resident in the UK (Office for National Statistics, 2011). Our research is part of a growing body of research focusing on the experiences of post-accession Polish migrants living in the UK (for example, Burrell, 2009; 2010; Garapich, 2008; Garapich and Eade, 2008; 2009; Garapich et al, 2009; Pietka, 2011, Rabikowska, 2010; Ryan and Sales, 2011; Ryan et al, 2009; White, 2009; 2011; White and Ryan, 2008). Our research contributes to this body because we foreground what Favell calls "the human face of migration" (2008, page 702) and what Burrell describes as "the personal experiences" of A8 or postaccession migrants in the UK (2009, page 12). This paper is based on twenty biographical interviews conducted with post-accession Polish migrants in their homes in Glasgow in 2010-11. 
The target group was adult Poles who had arrived in the UK following Poland's EU accession in May 2004. We aimed to achieve a diversified sample in terms of family circumstances and household characteristics. We thus applied purposive sampling, aiming at a 50/50 gender split, and 60/40 split of persons who had/did not have children. Moreover, participants were targeted according to household type: for example, couples with and without children, living with relatives with and without children, living with friends with and without children, oneperson households, and single-parent households. Study participants were recruited using a range of methods, including advertisements on websites for Poles living in the UK, in local Polish shops and community places (including libraries and Polish clubs), through formal networks and organisations, through personal networks, and snowballing. In table A1 (in the appendix) we provide some biographical information for all of the participants interviewed in Glasgow. Following Reeve (2008) this paper takes its place in a body of recent UK research that attempts to grapple with the changing nature of UK immigration and migration, in terms of the way in which new immigration and migration settlement is reshaping neighbourhoods and raising different challenges, but also opportunities, in different places. Usually, when immigrants or migrants and social housing are mentioned in the same sentence, it is to point out the social consequences of immigration and the impact on local housing and education markets. However, it is important to add complex understandings of the social consequences discourse (which might be more relevant to some parts of the UK: for example, the southeast of England, than others, for example, Scotland). In this paper we follow Robinson's (2007; 2010) lead when he calls for a more geographically dispersed perspective on the relationship between immigration/migration and housing needs. As such, we explore post-accession Polish migration to Glasgow and examine the relationship of these migrants with the social housing markets in this city.

According to Sim and Bowes, the political debate about immigration and migration in Scotland has been significantly different from that in England; this mostly reflects concerns about declining populations north of the border, and the Scottish Executive's campaigns to encourage more people to choose to live and work in Scotland (Sim and Bowes, 2007, page 743). These political debates in Scotland have been backed up with a variety of initiatives, for example, The Fresh Talent Initiative and the One Scotland Campaign, which have been introduced to educate the Scottish public about the positive impacts of migration (Lewis, 2006, page 6). We know that Poles and other A8 migrant workers have accessed social housing in other parts of Scotland. For example, Rolfe and Metcalf note that in certain parts of Edinburgh social housing has been offered to migrants with less than 12 months' residence; and there is evidence that migrants have accessed social housing in areas of low demand in Aberdeen too (Rolfe and Metcalfe, 2009, page 63). It should be noted that in England A8 nationals were eligible for 'social housing' only if they had been compliant with the relevant registration or authorisation scheme: for example, the Accession Registration Scheme (AWRS). These restrictions in England only ceased in April 2011 with the closure of the AWRS. However, in Wales and Scotland postaccession migrants have been able to apply for housing through housing association 'waiting lists' and homelessness assistance and this was irrespective of employment, registration, or authorisation in Scotland and Wales (Kofman et al, 2009, pages 91-92).

In terms of recent research on social housing in Glasgow, there are studies focusing on the relationship between housing association tenancy, regeneration, and the sustainability of social housing markets in Glasgow (see McIntyre and McKee, 2008; McKee, 2007; 2008). Furthermore, there have been a number of recent studies that have examined the housing and settlement of diverse ethnic groups in Glasgow, especially asylum seekers dispersed under the National Asylum Support Service, which was implemented after the Immigration and Asylum 
Act of 1999 (Ager and Strang, 2004; McGhee, 2005; Wren, 2004). In addition, Emilia Pietka (2011) has conducted research on coethnic relations amongst the post-accession Poles in Glasgow. However, to date there has been little specific research on the experiences of postaccession migrants accessing housing association accommodation and living on Glasgow's housing estates. In this paper we will begin to fill this gap in knowledge.

Glasgow is a city well known for bringing together a 'housing need' with a 'housing supply'. Post-accession Poles are the most recent population to fill the 'void' in Glasgow's 'unpopular' and therefore low-demand housing in areas of social deprivation (Audit Commission, 2007). In this paper we examine post-accession Polish migrants' perceptions of what Pred calls "the intersection of individual paths with institutional projects occurring at specific temporal and spatial locations" (1984, page 282); that is, the housing-seeking activities of migrants and the low-demand accommodation letting activities of, for example, the Glasgow Housing Association (GHA). ${ }^{(1)}$ Therefore, in this paper we examine the meanings, processes, experiences, and perceived advantages (for migrant families and for housing associations), and also the disadvantages, associated with postaccession Polish families taking up and being potentially 'steered' (Sarre et al, 1989, page 44) into tenancies in particular areas of Glasgow.

\section{Post-accession Europeans - achieving housing 'normality' in the UK}

This research is timely as there have been a number of media reports that suggest that Poles are leaving the UK to return to Poland in the context of the current economic downturn. Although this research was conducted during the economic downturn, we note that few of our interviewees had plans for returning to Poland - precisely because they find life 'easier' and affordable in the UK. Furthermore, most told us that they live a more 'dignified' and a generally happier life in the UK and they would experience a reduction in their standard of living, or that they would be unable to find work if they returned to Poland (McGhee et al, 2012). Other British academics have closely examined some of the complex structural factors that contribute to the settlement of post-accession migrants in the UK: for example, a few recent studies have suggested that the differences between the UK and Polish education systems are being perceived as a barrier to return for families with school-age children (Ryan and Sales, 2011; Sales et al, 2008; Trevena et al, 2010). Rather than focusing on employment and education, and its impact on the settlement practices of post-accession Poles, our focus in this paper is on housing - in particular, the experiences of accessing and living in low-demand social housing in Glasgow.

Throughout the paper we draw on a number of recent articles and reports that examine A8 or post-accession Polish housing and accommodation in the UK (for example, Audit Commission, 2007; Pemberton, 2009; Pemberton and Stevens, 2007; Perry, 2008; Robinson, 2009; Robinson and Reeve, 2006; Robinson et al, 2007; Rutter and Lattore, 2009; Spencer, 2006; Spencer et al, 2007). Like many new migrant groups, post-accession Poles enter the housing market at the lower end of the accommodation-quality spectrum (Perry, 2008, page 6; Robinson and Reeve, 2006, page 26). The common initial 'housing scenario' is accurately described by Robinson et al:

"focusing exclusively on the private rented sector, respondents typically stayed with a friend or relative as a guest for a week or two until they secured their own tenancy, typically in a house in multiple occupation" (2007, page 16).

(1) It should be noted that the GHA is the stock-transfer landlord that took over Glasgow City Council's housing stock. This is relevant because the local authority will still have responsibility under the terms of the homelessness legislation and will still use GHA's housing stock to meet their obligations. In this respect, the GHA is different from other housing associations in Glasgow. 
As noted by Robinson et al in their research in Sheffield, a more discerning attitude to quality of accommodation and who they live with (as well as where they live, in terms of area) emerged amongst their Polish participants when their circumstances changed (through, for example, family reunification) and/or with the realisation that their stay might be longer term (2007, page 57). In most cases this was associated with a process of incrementally improving their housing outcomes in the privately rented sector through their own resources (Markova and Black, 2007, page 29; Robinson et al, 2007, page 2). It should be noted that a common housing objective for our participants was to live independently as a couple or as a family unit: that is, independent of other tenants in the UK, or living independent of parents and inlaws, in Poland. The ability to afford to live as a couple and as a family independent of extended family in the UK is a major factor in many of our participants' 'settlement discourses'. For a number of our participants, returning to Poland would mean returning to 'extended-family' living, which they see as a major step backwards (Mandic, 2008; Roberts, 2009; White, 2011).

Most of our participants contrasted their housing experiences in Poland unfavourably with their current standards of housing in Scotland. There were three main points of contrast: (1) being able to afford to live outside of extended-family households; (2) being able to afford to live in better quality housing; and (3) being able to afford more spacious accommodation. For example, for Ryszard "the conditions for housing here and in Poland are incomparable". In Poland his family was living in a damp and crowded apartment of $38 \mathrm{~m}^{2}$, and he describes his accommodation in Glasgow with considerable pride:

"here, as you see, we have a flat that consists of three bedrooms, a living room and a beautiful big kitchen and a beautiful bathroom. And it's warm and dry."

Furthermore, to his astonishment, Ryszard has been offered an even bigger apartment by his housing association. Ola told us that the ability to afford to live independently of her parents was a major advantage and reason for staying in the UK; she told us:

"I can tell you that three quarters of my friends have also left my home town. And, the one quarter that has stayed, all still live with their parents."

Sylwester corroborated this, when he told us that all of his peers who have remained in his home town in Poland live with their parents and inlaws. Ewelina also contrasted her and her husband's previous experience of having to share a flat with extended-family members in Poland with being able to live with her partner and children as 'a family unit' in Glasgow:

"Here, I have a family home of my own, my own nest."

Renata told us that the ability, for the first time, to live away from parents and being able to afford the rent for her first house together with her boyfriend has resulted in her starting to "feel at home in her space". For Czesław and his family (in a similar vein to Ryszard above) migrating to Scotland was a case of escaping from grinding poverty (see also McGhee et al, 2012). In Glasgow, he told us, he, his wife, and their four children live in a comfortable and spacious flat where his sons and his daughters can have separate rooms- he contrasted this with his family's experience of living in a $47 \mathrm{~m}^{2}$ one-bed flat in Poland. A similar experience was relayed to us by Waldemar, who compares his spacious three-bedroom housing association flat in Glasgow with his experience of himself, his wife, and their six children living in a one-bedroom $70 \mathrm{~m}^{2}$ flat in Poland.

Our interviewees seem to be developing a new or, more accurately, revised perspective of what 'housing normality' is or should be as a result of their experiences of living in the UK. As such, our data analysed above lead us to observations made by Rabikowska when she said that migrants from postcommunist societies like Poland develop new versions of 'normality' as a consequence of migrating to the West (2010, page 288), which leads to the development of personal 'benchmarks' by which they assess appropriate and inappropriate 'standards 
of living' which can, in turn, impact on their plans for settling in the UK or returning to Poland. Furthermore, this new version of normality extends beyond the quality and quantity (in square metres) of the accommodation in the Scotland compared with that in Poland; it also extends to a sense of security that tenancy and access to other benefits provides for them and their families in the UK, which they compare with what they view to be the inadequate welfare system in Poland. For example, Czesław contrasts his family's situation in Scotland with that in Poland:

"In Poland if you lose your job-who cares? You have to continue making all the payments and if you don't - they'll throw you out of your flat. And you're left with nothing! And here if you lose your job, they'll pay all your expenses ... so even if I lose my job, I have kids in school here, I won't be left to my own devices. I'll always receive some help. And in Poland you could only dream about such things ... and that's why I don't feel the urge to go back."

Like Czesław, Ryszard also describes the enormous peace of mind that the British welfare state gives him:

"here, if anything bad happens to me (hopefully it won't because I'd still like to live a little), my wife and children would get taken care of. In Poland they would never have that. So I have peace of mind."

A number of our interviewees conflated this sense of security (associated with being able to access the British welfare state) with being a social housing tenant. However, in reality, the only real difference between themselves and tenants in the private sector is that housing benefits for housing association tenants cover their entire rent, rather than just a proportion of it. For some of our participants, their housing association tenancy (as opposed to a private sector tenancy) and the safety net of receiving housing benefit if they lose their jobs have become a source of comfort in uncertain times. Blazej explained this to us:

"If you lose your job no one can throw you out of such a flat. It is enough for you to register with a job centre and apply for housing benefit and the state covers your rent ... it's a welfare state here, and this is some kind of safety net."

In the rest of this paper we examine the processes through which our participants have accessed these tenancies and we examine their experiences of living in 'waiting list' flats in some of Glasgow's low-demand housing areas.

\section{Accessing low-demand social housing in Glasgow}

A number of our participants were not successful in getting housing association accommodation through the points system. For example, some of our younger participants, who were either single or in couples, but without children, had been unsuccessful (due to having insufficient points) in their applications for housing association accommodation. Some of this group were offered housing association flats available on the 'waiting list' (see below), only to turn them down. For example, Anita suggested that the reason that she had been unsuccessful in her previous housing association applications was that she did not have enough points because she was not, in her words, "a divorcee and did not have children". Anita also informed us that she was actually offered a 'waiting-list flat' which she turned down because, after viewing the flat, her conclusion was that the "area was so grim and scary that I would be afraid to come out of the flat". For Anita, the housing associations in Glasgow were using Poles to fill low-demand waiting-list housing in 'bad' areas:

"I think the housing associations like to throw Polish people into these kinds of places and there are a lot of desperate people out there who will accept any conditions. We've actually turned down a number of offers over the years."

According to Tribal Consulting, a social research organisation who were commissioned by Glasgow Housing Authority to examine housing and migration in Glasgow, Poles and 
other A8 migrants are willing to take up properties which are available due to "structural demand issues and 'slack' within the social rented sector" (2008, page 9). In the process of their research, Tribal Consulting noted a dramatic increase in the ethnic monitoring category 'white other' applications to Glasgow Housing Authority, with a 234\% increase in applications between 2004 and 2005, and "this growth has continued year on year since" (page 9). They also noted an increase in housing allocations to 'white other' tenants, with $89 \%$ of these allocations of properties coming from applications through the general 'waiting lists' (page 9). According to Tribal Consulting, allocations from the general waiting list implies that a relatively "low level of need was required to obtain a tenancy"; that these properties were 'low-demand' and thus 'readily available' (page 9). These are the types of properties that some of our participants, for example, Anita (see above), have been offered repeatedly but have turned down. However, a number of our participants have taken up these flats across Glasgow and it is to their experiences of living in these flats in particular areas of Glasgow that we now turn.

It should be stated that all of our participants had a choice: that is, either to take up accommodation in the private rented market, or to take up what they perceive to be the more secure tenancies and less expensive (subsidised) housing association accommodation. As noted above, the vast majority of our participants who took this second option chose to take up 'waiting-list flats'. There are numerous examples of our participants informing us just how easy it is for Poles (and, for that matter, anyone else) to access 'waiting-list flats'. For example, Urszula informed us that not only has she and her 28-year-old daughter each been given their own waiting-list flat, the housing association are also eager to house her 18-year-old son too. Agnieszka told us that securing her 'waiting-list flat' was "a very speedy process", and that, subsequent to her and her family getting their flat, her parents were also given a 'waiting-list flat' nearby in Glasgow. A number of members of Błażej's family seem to live in their own housing association flats across Glasgow: he has one; his sister has one; his father has one; and his mother (who is separated from his father) also lives with Błażej's younger sister in a housing association flat. His family is an example of what Pietka calls the "relocation of close family relationships from Poland to Glasgow" (2011, page 136). The general impression of the ease with which housing association flats can be obtained was articulated by Ryszard, who informed us that if his frail 80 -year-old mother was to come over from Poland and if she decided to stay, he has no doubt that if his housing association were informed about the situation "she would immediately be allocated a flat here on the ground floor, with wheelchair access." Ryszard informed us that "this isn't Poland. Here they give you a flat with wheelchair access."

This ease of getting flats through the waiting list also appears to be having particular impacts on local areas in Glasgow, according to our participants. A number of our interviewees referred to living in 'Polish areas', that is, post-accession Polish areas, in Glasgow. For example, Anita told us that in her previous neighbourhood "I could easily say that every other neighbour of ours was Polish." Similarly, Jerzy informed us that the housing estate in which he lives "is considered to be 'half Polish'." These perspectives on the presence of other Poles living in particular neighbourhoods in Glasgow are corroborated by Tribal Consulting, who suggested a clustering of A8 migrants in specific areas of Glasgow. They put this down to "the availability of Glasgow Housing Association stock but it also demonstrates the 'snowball' effect where housing choices were influenced by 'word of mouth' information amongst migrant communities" (2008, page 5). This process is also facilitated by the housing associations and other organisations in the city that provide advice for new migrants and encourage them to take up some of the 'hard-to-let' properties in the city (we develop this in the penultimate section). But what do our respondents think about their new neighbourhoods 
and the neighbourhoods they have moved into? What are the perceived advantages and disadvantages of taking up these tenancies?

\section{Living in areas experiencing multiple social problems}

A number of our participants expressed their surprise when they discovered that many of their new Glaswegian neighbours were what our participants called 'life-long welfare dependents'. For example, Błazej was astounded to discover that one of his neighbours, who was in his fifties, "had never worked a day in his life". Some of our participants also informed us that these Scots viewed migrants such as Poles in a very positive light. This alternative Polish discourse subverts and marginalises a number of aspects of the anti-immigration 'social consequences' discourse in the UK associated with the alleged 'downsides' of immigration and migration into Britain associated with competition for 'British' jobs, housing, and local services. According to Błazej, it is his contribution to the labour market and the associated taxes he pays from this wage labour that result in Poles like himself being viewed positively by what he describes as the "welfare-dependent" Scots on his estate. For Błazej these Scots do not view him and fellow Poles as competitors for jobs or houses; rather, "they know that immigrants, Poles and others, will come to work and pay the taxes, and they'll get their benefits."

The vast majority of our respondents were very keen to tell us how welcoming, friendly, and helpful they found Glaswegians to be. The overall impression from our respondents in Glasgow was the city was welcoming to Poles. Poles are the most recent influx in a long history of White/European migrants into the city in the last two hundred years, including internal migrations from the Scottish Highlands, Irish migration, and a number of waves of various European nationalities (Edwards, 1993). As a result, Glasgow is predominately a 'white' city (Sim and Bowes, 2007, page 742); only 5.5\% of its 2001 population are nonwhite - mostly Pakistanis and South Asian communities (Lewis, 2006, page 20). Despite the Scottish Executive's attempts to present the welcoming face of Scotland to all newcomers, there is research that indicates that the influx of dispersed asylum seekers to Glasgow in the last decade has become a source of tension in local areas (Lewis, 2006; McGhee, 2005; 2006). Poles, as White Europeans, do not seem to have attracted some of the negativity and hostility that non-European asylum seekers have experienced. However, we are finding, as noted above, that some of our participants hold negative and stereotypical views of their Glaswegian neighbours. For example, Jowita talks about a neighbourhood a few streets from where she lives, in particular terms - that is, as an enclave of intergenerational subcultural social exclusion:

"my friend lives a few streets away and there are more older families there, older in the sense that they've been living there for years and there are more subcultures there ... they wander around in tracksuits and I don't think they go to school or work."

Another example came from Karolina, who refers to her own neighbourhood as being full of "dodgy characters" who "live in squalor and are alcoholics". We have noted that our respondents were engaging in the use of stereotypes that result in the 'othering' of some of their Glaswegian neighbours. Grove and Zini describe this process thus:

" 'othering' defines and secures one's own identity by distancing and stigmatising an

(other). Its purpose is to reinforce notions of our own "normality"' (2006, page 1933).

Thus, this process of othering acts simultaneously to distinguish what our interviewees present as 'hard-working' Poles (like themselves) from what they view to be Glasgow's socially excluded subpopulations with whom they often live side-by-side on these estates. In a sense, our participants' "revisions of normality" (Rabikowska, 2010, page 288), associated with their comparison of their housing standards with arrangements (that is, living in extendedfamily households) in Poland compared with living in what they view to be appropriate 
housing in Scotland, comes with a price in terms of the quality of their neighbourhood and neighbours in Glasgow.

Being a housing association tenant might provide many of our participants with a sense of stability (and 'normality' in terms of living in what they see to be appropriate housing for their needs). However, for some, living in such areas can compromise their sense of personal safety. Czesław told us that he knows of Polish families who live in what he calls "terrible areas" where they seem to be the only "ordinary family" living amongst "drug addicts and the like". He informs us that in Glasgow "there are such streets and such areas". Czarek told us:

"Glasgow is a dangerous town. It is a town where lots of people have problems with addictions, where there is lots of antisocial behaviour, where there are fights; they call it sectarianism and territorialism. They say the clan culture still exists here."

Renata referred to her area as being like 'the Wild West': she described the youth in her area in a particular way, in that she calls them (picking up on the vernacular stereotypical categorisation of antisocial male youths in Glasgow) "the "ned' type of youth". Like Renata, Jowita also uses the local vernacular to refer to young people on her estate as 'neds':

"the so-called 'neds' have become almost another social class here. They are young people, usually uneducated and with no clear goal in life. They get involved in fights and generally cause trouble. They are loud and aggressive."

Renata informed us that she had devised an intimate knowledge of her estate in order to maximise her personal safety: she told us that she has learned "where to go and where I wouldn't like or shouldn't go" in order to try to avoid coming into contact with 'neds'. Agnieszka reflects on other people's reactions when she tells people where she lives.

"Generally, when I tell people where I live, they react with considerable horror, often exclaiming 'people get killed there!'."

There is evidence of some ambiguity with regard to the extent to which a sense of security and safety has or has not been an obstacle to our interviewees integrating into their neighbourhoods (Ager and Strang, 2004). For example, Agnieszka informed us that her neighbourhood has begun to feel like home, and for her and her father (who also has his own housing association flat in her area) it feels like "a small village where everyone knows each other". This appears to be 'the daytime' experience, which she contrasts with the 'nighttime' experience on her estate which she associates with 'scary youths' whom she has learnt never to confront. She told us of an incident which for her demonstrated the reputation which her neighbourhood has for people from other parts of Glasgow when she recalled for us a recent encounter with a computer repair man who refused to return to repair her computer in the evening because he was too scared to drive through her neighbourhood after $7.00 \mathrm{pm}$. Ryszard informed us that his estate is what he calls a 'wild zone' in the evenings. He talked about Friday nights on his estate, in particular, as a night when "the teenagers rule", that is,

"on Fridays anyone who thinks logically and doesn't have the need to leave their house and go to the shops doesn't do this ... for them to hit you on the head with a bottle is normal."

It is clear from these extracts that the achievement of a sense of stability through achieving housing association tenancy in these areas of Glasgow is both potentially enabling and constraining for these migrants. The 'deprived areas' they have settled in can be welcoming and friendly. However, they are also associated with multiple social problems, beyond the obvious antisocial behaviour and threatening presence of the youth on the estates. 


\section{Migrant social housing tenancy and housing association projects for populating low demand areas in Glasgow}

As noted above, a common theme across our interviews concerns many Poles being allocated 'waiting-list flats' that many Scots (and, as noted above, some Poles) would not take themselves. For example, Waldemar choose to live as cheaply as possible in Glasgow without having to live in shared accommodation. His objective was to keep his expenses down so he could send money back to his family in Poland each month. He lives on the 28 th floor of a 30 -floor tower block - he told us that he is getting used to living in a block populated by what he calls 'deprived' Scots, ethnic minorities, and asylum seekers. He also told us that his and neighbouring blocks of flats have a reputation for being the location of 'fake suicides' (that is, murders) involving local 'mafia' throwing people out of windows. Urszula suggested that housing associations are actually using what she calls "refurbishing Poles" to "do up" (at their own expense) flats in very poor condition:

"I think they take advantage of the situation. A Scottish person would never accept a flat like that. I wouldn't either if it wasn't so important to me ... it makes a lot of sense to a housing association though ... to get a Polish person in, as they are most likely to redecorate. Like in my case, I left them a refurbished, repainted flat."

Could the incorporation, so the post-accession Polish discourse goes, of tax-paying, "hardworking' Poles interspersed amongst the tenants of some of these areas be part of what Pred would call a "locally occurring institutional project" (1985, page 342)? Rather than postaccession Poles being viewed as competitors for scarce social housing (Perry, 2008; Robinson, 2007), could they be being viewed by local housing associations as a revitalising force for transforming low-demand housing and regenerating particular areas? Whether the individual paths of these families have 'intersected' with particular local institutional projects or not, there is some evidence of housing associations attempting to facilitate this process through throwing what Henryk calls 'integration parties' on estates; and the setting up, for example, of a New Residents of Govan Association which, according to Urszula (who describes herself as an active member), has been set up specifically to help Polish people by giving them "advice on how to look for a flat or receive a benefit". There is also evidence that the GHA and other local housing associations in Glasgow are viewing the influx of A8 migrants into the city as a potential opportunity:

"it offers new opportunities for the GHA in letting properties that may have been more difficult to let in the past and in adding more working households to the tenant base"

(Tribal Consulting, 2008, page 9).

According to research conducted by Blake Stevenson Ltd (a private social research organisation) and commissioned by Glasgow City Council, a number of housing associations across Glasgow - for example, Glenoaks Housing Association, GHA, Shaws Housing Association, and Govan Housing Association-have employed specific workers and have had tenancy agreements translated into A8 languages (2007, page 50). Although a number of these housing associations have made specific deals with specific employers (for example, First Bus) to accommodate their workers from Poland, Govan Housing Association appears to be the most proactive in their attempts to attract A8 tenants. According to Blake Stevenson Ltd's report, Govan Housing Association holds open days for A8 nationals, and the first open day was "attended by over 500 people" (page 50). Blake Stevenson Ltd stated that the majority of A8 migrants who had attended Govan Housing Associations' open days and have subsequently taken up tenancies were from Poland (page 50).

According to Jordan, just as phrases from the language of 'their hosts' creep into migrant Poles' speech (for example, the noun 'neds' and the retelling of local myths such as 'fake suicides'), so too might practices and ways of thinking also be transferred from 
'hosts' to new arrivals (2006, page x). What we have highlighted through our interviews are examples of what Morawska describes as migrants "playing with" and also "playing against" different structures in these contexts (2001, page 54). However, as noted above, there is a subtext discernable in our interviews in which some Polish families feel as if they are being 'used' by housing associations as well as being 'channelled' or 'steered' (Sarre et al, 1989, page 44; pages 318-319) into taking up 'waiting-list flats' in low-demand areas blighted by considerable social problems. There are potential advantages for housing associations associated with an influx of immigrant and migrant families into local hard-to-let, lowdemand housing areas and there are advantages for migrant families too, as articulated by our respondents in terms of getting access to subsidised and therefore affordable accommodation and achieving a sense of security through these tenancies (and their belief that these tenancies give them 'greater' access to the welfare system than would a tenancy in the private rented sector). But there are also disadvantages. As noted above, there was no sense from our respondents that Poles were the explicit target of an anti-migrant backlashquite the opposite in fact: Glasgow as a whole was seen as a very welcoming place to new Polish migrants. The 'integration parties' held on estates, as mentioned above, have been specifically introduced to ease tensions that have emerged in recent years-especially when large numbers of new arrivals (asylum seekers in particular) have been dispersed to housing estates in Glasgow (McGhee, 2005). Concerns about personal safety were articulated by our interviewees in terms of an ambient fear associated with the presence of 'antisocial youth' on the estates. That being said, there are perhaps mid-term to longer term potential effects that are yet to emerge in the lived realities of our respondents living on these estates in Glasgow. These could emerge in the future in the form of disadvantages that could impact on these families living in 'deprived areas': for example, poor educational achievement, and raising their children in areas characterised by a range of other social problems that Polish parents might not be able to insulate their children from.

\section{Conclusion}

In this paper we have examined what could potentially be viewed as a localised interplay of migrant workers and their families with what could be seen to be part of a wider phenomenon in Glasgow and in other Scottish cities (Rolfe and Metcalfe, 2009), where Polish and other migrants are accessing housing association accommodation in particular low-demand areas. In many ways what we present in this paper could contribute to an alternative discourse to the housing-focused 'social consequences' discourses that abound in the UK-especially since immigrants and migrants accessing social housing is not just a Scottish phenomenon. The ending of the AWRS restrictions on accession-state nationals accessing social housing in England in April 2011 could result in an increase in post-accession migrants' applications for housing association and other social housing in many more areas across the UK. Despite these restrictions existing, there is evidence that immigrant and migrant populations are also accessing and allegedly having 'a positive impact' on 'housing renewal areas' in certain English cities too-cities which, like some Scottish cities, also have particular areas with concentrations of low-demand housing. According to the Audit Commission (referring to the social and privately rented housing markets in these housing renewal areas in English cities), "some of these areas are now finding that local demand has picked up because of migrant workers, helping to raise prices and reduce the number of empty properties" (2007, page 22).

We support Robinson in his championing of a wider and more geographically dispersed perspective on the relationship between immigration/migration and housing needs in the UK. However, this paper makes a critical contribution to what Robinson and Reeve refer to as the "small and growing literature" that also suggests that new migrants and immigrants are, in some cases, making a positive contribution to "the regeneration and revitalisation 
of declining neighbourhoods" (2006, page 33). Our critical contribution to these literatures comes from our examination of the lived realities (for migrants) associated with the taking up of low-demand social housing in these areas of the UK. We have focused on the variety of processes, meanings, and experiences of post-accession Polish housing association tenants in Glasgow. We have attempted to present a balanced interpretation of our Polish respondents' perceptions of the advantages of achieving housing association tenancy in low-demand housing areas in Glasgow and we have also presented their perspectives on some of the downsides of actually living in these areas.

What we found in our interviews is a willingness to compromise certain aspects of safety in terms of our participants' immediate environments in some of these areas of Glasgow for the sense of 'security' acquired through being a social housing tenant. Added to this is the contrast between their housing biographies in Poland (experienced as poor-quality housing in cramped, extended-family households) which they compare with the perceived 'normality' of living independent of extended families in more spacious flats in Glasgow. Thus, what Ager and Strang refer to as the measures of indicators of appropriate housing, which include a range of factors - "the physical size, qualities and facilities of housing, along with the financial security of tenancies" (2008, page 171) - seem to counteract certain 'safety and security issues' associated with their housing environments, including proximity to populations with multiple social problems (page 172). Perhaps the key to understanding this compromise is the understanding of what a housing association tenancy actually means (whether correctly or incorrectly) for some of our participants: that is, their belief that a social housing tenancy gives them privileged access to welfare protection if their circumstances change, for example, through losing their jobs.

\section{References}

Ager A, Strang A, 2004 The Experience of Integration: A Qualitative Study of Refugee Integration in the Local Communities of Pollockshaws and Islington Home Office, London

Ager A, Strang A, 2008, "Understanding integration: a conceptual framework" Journal of Refugee Studies 21(2) 166-191

Audit Commission, 2007 Crossing Borders: Responding to the Local Challenges of Migrant Workers Audit Commission, London

Blake Stevenson Ltd, 2007 A8 Nationals in Glasgow report for Glasgow City Council

Burrell K, 2009, "Introduction: migration to the UK from Poland: continuity and change in EastWest European mobility", in Polish Migration to the UK in the New European Union after 2004 Ed. K Burrell (Ashgate, Aldershot, Hants) pp 1-24

Burrell K, 2010, "Staying, returning, working and living: key themes in current academic research undertaken in the UK on migration movements from Eastern Europe" Social Identities $\mathbf{1 6}$ 297-308

Edwards M, 1993 Who Belongs to Glasgow? Glasgow Libraries, Glasgow

Favell A, 2008, "The new face of East-West migration in Europe" Journal of Ethnic and Migration Studies 36 701-716

Garapich M, 2008, "Odyssean refugees, migrants and power: construction of the 'other' within the Polish community in the United Kingdom", in Citizenship, Political Engagement and Belonging: Immigrants in Europe and the United States Eds D Reed-Danahay, C Brettlee (Rutgers University Press, New Brunswick, NJ) pp 124-144

Garapich M, Eade J, 2008, "Settling and surviving in London? The experience of Poles and other A8 migrants in a global city", in Accession and Migration: Changing Policy, Society and Culture in an Enlarged Europe Eds J Eade, Y Valkanova (Ashgate, Aldershot, Hants) pp 21-40

Garapich M, Drinkwater S, Eade J, 2009, "Poles apart? EU enlargement and the labour market outcomes of immigrants in the UK" International Migration 47 161-190

Grove N, Zini A, 2006, "Our health and theirs: forced migration, othering and public health" Social Science and Medicine 62 1931-1942 
Home Office, 2009 Accession Monitoring Report, May 2004-March 2009: A8 Migrants Home Office, London

Immigration and Asylum Act, 1999 Public General Acts-Elizabeth II chapter 33 (The Stationery Office, London)

Jordan B, 2006, "Foreword", in Contemporary Polish Migration in Europe: Complex Patterns of Movement and Settlement Ed. A Triandafyllidou (Edwin Mellen Press, Lewiston, NY) pp ix-x

Kofman E, Lukes S, D'Angelo A, Montagna N, 2009 The Equality Implications of being a Migrant in Britain Equality and Human Rights Commission, Manchester

Lewis M, 2006 Warm Welcome: Understanding Public Attitudes to Asylum Seekers in Scotland Institute for Public Policy, http://www.ippr.org

McGhee D, 2005 Intolerant Britain? Hate, Citizenship and Difference (Open University Press, Milton Keynes, Bucks)

McGhee D, 2006, "Getting 'host' communities on board-finding the balance between 'managed migration' and 'managed settlement' in community cohesion strategies" Journal of Ethnic and Migration Studies 32 111-128

McGhee D, Heath S, Trevena P, 2012, "Dignity, happiness and being able to live a 'normal life' in the UK - an examination of post-accession Polish migrants' transnational autobiographical fields" Social Identities 18 711-727

McIntyre A, McKee K, 2008, "Governance and sustainability in Glasgow: connecting symbolic capital and housing consumption to regeneration" Area 40 481-490

McKee K, 2007, "Community ownership in Glasgow: the devolution of ownership and control, or a centralizing process?" International Journal of Housing Policy 7 319-336

McKee K, 2008, "The 'responsible' tenant and the problem of apathy" Social Policy and Society $825-36$

Mandic S, 2008, "Home-leaving and its structural determinants in Western and Eastern Europe: an exploratory study" Housing Studies 23 615-637

Markova E, Black R, 2007 East European Immigration and Community Cohesion Joseph Rowntree Foundation, York

Morawska E, 2001, "Structuring migration: the case of Polish income seeking travellers to the West" Theory and Society 30 47-80

Office for National Statistics, 2011 Migration Statistics Quarterly Report November 2011Statistical Bulletin http://www.ons.gov.uk/ons/rel/migration1/ migration-statistics-quarterly-report/ november-2011/msqr.html

Pemberton S, 2009, "Economic migration from EU 'A8' accession countries and the impact on lowdemand housing areas" Urban Studies 46 1363-1384

Pemberton S, Stevens C, 2007 Economic Migration to Housing Market Renewal Areas in North West England - Opportunity or Threat? Merseyside Social Inclusion Observatory Policy Report 4

Perry J, 2008 The Housing and Neighbourhood Impact of Britain's Changing Ethnic Mix Joseph Rowntree Foundation, York

Pietka E, 2011, "Encountering forms of co-ethnic relations: Polish community in Glasgow" Studia Migracyjne-Prezeglad Polonijy 139 129-152

Pollard N, Lattore M, Sriskandarajah D, 2008 Floodgates or Turnstiles? Post-EU Enlargement Migration Flows to (and from) the UK (Institute for Public Policy Research, London)

Pred A, 1984, "Places as historically contingent process: structuration and the time geography of becoming places" Annals of the Association of American Geographers 74 279-297

Pred A, 1985, "The social becomes the spatial: the spatial becomes the social: enclosures, social change and the becoming of places in the Swedish province of Skane", in Social Relations and Spatial Structures Eds D Gregory, J Urry (Macmillan, Basingstoke, Hants) pp 337-365

Rabikowska M, 2010, "Negotiating normality and identity among migrants from Eastern Europe to the United Kingdom after 2004" Social Identities 16 285-296

Reeve K, 2008, "New immigration and neighbourhood change", in Community Cohesion in Crisis? Eds J Flint, D Robinson (Policy Press, Bristol) pp 77-198

Roberts K, 2009 Youth in Transition: Eastern Europe and the West (Palgrave Macmillan, Basingstoke, Hants) 
Robinson D, 2007, "European Union accession state migrants in social housing in England" People, Place and Policy On-Line 1(3) 98-111

Robinson D, 2009, "New immigrants and migrants in social housing in Britain: discursive themes and lived realities" Policy and Politics 10 1-21

Robinson D, 2010, "Neighbourhood effects of new immigration" Environment and Planning A 42 2451-2466

Robinson D, Reeve K, 2006 Neighbourhood Experiences of New Immigration Joseph Rowntree Foundation, York

Robinson D, Reeve K, Casey R, 2007 The Housing Pathways of New Immigrants Joseph Rowntree Foundation, York

Rolfe H, Metcalf H, 2009 Recent Migration into Scotland: The Evidence Base Scottish Government Social Research, http://www.scotland.gov.uk/Publications/ 2009/02/23154109/0

Rutter J, Latorre M, 2009 Social Housing Allocation and Immigrant Communities Equality and Human Rights Commission, Manchester

Ryan L, Sales R, 2011, "Family migration: the role of children and education in family migration decision-making" International Migration, doi:10.1111/j.1468-2435.2010.00652.x

Ryan L, Sales R, Tilki M, Siara B, 2009, "Family strategies and transnational migration: recent Polish migrants in London" Journal of Ethnic and Migration Studies 35 61-77

Sales R, Ryan L, Lopez Rodriguez M, D’Angelo A, 2008 Polish Pupils in London Schools: Opportunities and Challenges Social Policy Research Centre, Middlesex University, Hendon, London

Sarre P, Phillips D, Skellington R, 1989 Ethnic Minority Housing: Explanations and Policies (Avebury, Aldershot, Hants)

Sim D, Bowes A, 2007, "Asylum seekers in Scotland: the accommodation of diversity" Social Policy and Administration 41 729-746

Spencer S, 2006, "Refugees and other new migrants: a review of the evidence of successful approaches to integration" (COMPAS, Oxford)

Spencer S, Ruhs M, Anderson B, Rogaly B, 2007 Migrants'Lives beyond the Workplace Joseph Rowntree Foundation, York

Trevena P, Heath S, McGhee D, 2010, "Polish migrants and schooling: the significance of experiences and perceptions of the British education system on migration decisions", paper presented at "Children, Families, and the Migration Experience: Opportunities and Challenges", 21 May, Middlesex University; copy available from the authors

Tribal Consulting, 2008 Housing Migrant Workers: the Impact on Glasgow Housing Association Glasgow Housing Association Ltd, 173 Trongate, Glasgow

White A, 2009, "Family migration from Polish small towns in Western Europe: a livelihood strategy approach", in Polish Migration to the UK in the New European Union after 2004 Eds K Burrell (Ashgate, Aldershot, Hants) pp 67-86

White A, 2011 Polish Families and Migration since EU Accession (Policy Press, Bristol)

White A, Ryan L, 2008, "Polish 'temporary' migration: the formation and significance of social networks" Europe-Asia Studies 60 1467-1502

Wren K, 2004 Building Bridges: Local Responses to the Resettlement of Asylum Seekers in Glasgow Scottish Centre for Research on Social Justice, University of Glasgow 


\section{Appendix}

Table A1. Participants.

\begin{tabular}{|c|c|c|c|c|c|c|c|}
\hline Name & Age & $\begin{array}{l}\text { Migrated } \\
\text { from }^{\mathrm{a}}\end{array}$ & Arrival & Family & $\begin{array}{l}\text { Current } \\
\text { occupation } \\
\text { in UK }\end{array}$ & $\begin{array}{l}\text { Former } \\
\text { occupation } \\
\text { in Poland }\end{array}$ & Education \\
\hline Agnieszka & 27 & $\begin{array}{l}\text { small town } \\
\text { in southern } \\
\text { Poland }\end{array}$ & 2006 & $\begin{array}{l}\text { Married, } \\
\text { one child }\end{array}$ & cleaner & barmaid & $\begin{array}{l}\text { general } \\
\text { secondary } \\
\text { ('A' levels) }\end{array}$ \\
\hline Anita & 28 & $\begin{array}{l}\text { large town } \\
\text { in western } \\
\text { Poland }\end{array}$ & 2007 & $\begin{array}{l}\text { married, } \\
\text { no children }\end{array}$ & $\begin{array}{l}\text { lead team } \\
\text { organiser }\end{array}$ & $\begin{array}{l}\text { marketing } \\
\text { assistant }\end{array}$ & $\begin{array}{l}\text { higher } \\
\text { (master's } \\
\text { degree) }\end{array}$ \\
\hline Błażej & 30 & $\begin{array}{l}\text { medium- } \\
\text { size town in } \\
\text { central-east } \\
\text { Poland }\end{array}$ & 2004 & single & $\begin{array}{l}\text { joiner (self- } \\
\text { employed) }\end{array}$ & $\begin{array}{l}\text { ran own } \\
\text { computer } \\
\text { business }\end{array}$ & $\begin{array}{l}\text { general } \\
\text { secondary } \\
\text { ('A' levels) }\end{array}$ \\
\hline Czarek & 31 & $\begin{array}{l}\text { big city in } \\
\text { western } \\
\text { Poland }\end{array}$ & 2007 & single & $\begin{array}{l}\text { counsellor } \\
\text { and psycho- } \\
\text { therapist }\end{array}$ & $\begin{array}{l}\text { higher } \\
\text { education } \\
\text { institution } \\
\text { lecturer }\end{array}$ & $\begin{array}{l}\text { higher } \\
\text { (master's } \\
\text { degree) }\end{array}$ \\
\hline Czesław & 35 & $\begin{array}{l}\text { village in } \\
\text { northern } \\
\text { Poland }\end{array}$ & 2007 & $\begin{array}{l}\text { married, } \\
\text { four } \\
\text { children }\end{array}$ & $\begin{array}{l}\text { part-time } \\
\text { cleaner }\end{array}$ & carpenter & $\begin{array}{l}\text { further } \\
\text { education } \\
\text { (FE) } \\
\text { vocational }\end{array}$ \\
\hline Ewelina & 30 & $\begin{array}{l}\text { medium- } \\
\text { size town } \\
\text { in central } \\
\text { Poland }\end{array}$ & 2005 & $\begin{array}{l}\text { married } \\
\text { to British } \\
\text { man, one } \\
\text { child }\end{array}$ & $\begin{array}{l}\text { physio- } \\
\text { therapist }\end{array}$ & $\begin{array}{l}\text { assistant } \\
\text { nurse (part- } \\
\text { time) }\end{array}$ & $\begin{array}{l}\text { qualified } \\
\text { physio- } \\
\text { therapist }\end{array}$ \\
\hline Henryk & 45 & $\begin{array}{l}\text { medium- } \\
\text { size town in } \\
\text { northwest } \\
\text { Poland }\end{array}$ & 2006 & married & cleaner & $\begin{array}{l}\text { carer in } \\
\text { animal } \\
\text { shelter }\end{array}$ & $\begin{array}{l}\mathrm{FE} \\
\text { vocational }\end{array}$ \\
\hline Jadzia & 32 & $\begin{array}{l}\text { medium- } \\
\text { size town in } \\
\text { northwest } \\
\text { Poland }\end{array}$ & 2006 & married & $\begin{array}{l}\text { sorter in a } \\
\text { laundry }\end{array}$ & $\begin{array}{l}\text { factory } \\
\text { worker }\end{array}$ & $\begin{array}{l}\text { FE } \\
\text { vocational }\end{array}$ \\
\hline Jerzy & 52 & $\begin{array}{l}\text { medium- } \\
\text { size town } \\
\text { in northern } \\
\text { Poland }\end{array}$ & 2006 & $\begin{array}{l}\text { married, } \\
\text { two } \\
\text { children }\end{array}$ & $\begin{array}{l}\text { home } \\
\text { support } \\
\text { worker }\end{array}$ & $\begin{array}{l}\text { veterinary } \\
\text { assistant }\end{array}$ & $\begin{array}{l}\text { secondary } \\
\text { vocational }\end{array}$ \\
\hline Jowita & 37 & $\begin{array}{l}\text { small town } \\
\text { in central } \\
\text { Poland }\end{array}$ & 2008 & $\begin{array}{l}\text { married, } \\
\text { one child }\end{array}$ & housewife & $\begin{array}{l}\text { ran own } \\
\text { training } \\
\text { business }\end{array}$ & $\begin{array}{l}\text { general } \\
\text { secondary } \\
\text { ('A' levels) }\end{array}$ \\
\hline Karolina & 27 & $\begin{array}{l}\text { big city in } \\
\text { southwest } \\
\text { Poland }\end{array}$ & 2007 & single & $\begin{array}{l}\text { temporarily } \\
\text { unemployed; } \\
\text { previously } \\
\text { construction } \\
\text { designer }\end{array}$ & student & $\begin{array}{l}\text { higher } \\
\text { (master's } \\
\text { degree) }\end{array}$ \\
\hline Monika & 31 & $\begin{array}{l}\text { large town } \\
\text { in northern } \\
\text { Poland }\end{array}$ & 2008 & divorced & $\begin{array}{l}\text { student/ } \\
\text { receptionist }\end{array}$ & $\begin{array}{l}\text { finance } \\
\text { officer }\end{array}$ & $\begin{array}{l}\text { higher } \\
\text { (master's } \\
\text { degree) }\end{array}$ \\
\hline Ola & 27 & $\begin{array}{l}\text { large town } \\
\text { in eastern } \\
\text { Poland }\end{array}$ & 2005 & $\begin{array}{l}\text { married, } \\
\text { one child }\end{array}$ & $\begin{array}{l}\text { full-time } \\
\text { homemaker }\end{array}$ & $\begin{array}{l}\text { social } \\
\text { worker }\end{array}$ & $\begin{array}{l}\text { general } \\
\text { secondary } \\
\text { ('A' levels) }\end{array}$ \\
\hline
\end{tabular}


Table A1. Continued.

\begin{tabular}{|c|c|c|c|c|c|c|c|}
\hline Name & Age & $\begin{array}{l}\text { Migrated } \\
\text { from }^{\mathrm{a}}\end{array}$ & Arrival & Family & $\begin{array}{l}\text { Current } \\
\text { occupation } \\
\text { in UK }\end{array}$ & $\begin{array}{l}\text { Former } \\
\text { occupation } \\
\text { in Poland }\end{array}$ & Education \\
\hline Paweł & 34 & $\begin{array}{l}\text { large town } \\
\text { in western } \\
\text { Poland }\end{array}$ & 2006 & single & $\begin{array}{l}\text { student/shop } \\
\text { assistant }\end{array}$ & $\begin{array}{l}\text { insurance } \\
\text { broker }\end{array}$ & $\begin{array}{l}\text { higher } \\
\text { (master's } \\
\text { degree) }\end{array}$ \\
\hline Renata & 24 & $\begin{array}{l}\text { large } \\
\text { town in } \\
\text { northwest } \\
\text { Poland }\end{array}$ & 2007 & $\begin{array}{l}\text { single, } \\
\text { cohabiting }\end{array}$ & $\begin{array}{l}\text { student/ } \\
\text { counter } \\
\text { assistant }\end{array}$ & student & $\begin{array}{l}\text { general } \\
\text { secondary } \\
\text { ('A' levels) }\end{array}$ \\
\hline Ryszard & 52 & $\begin{array}{l}\text { medium- } \\
\text { size town } \\
\text { in southern } \\
\text { Poland }\end{array}$ & 2008 & $\begin{array}{l}\text { married, } \\
\text { three } \\
\text { children }\end{array}$ & $\begin{array}{l}\text { self- } \\
\text { employed } \\
\text { (renovation } \\
\text { work, etc) }\end{array}$ & $\begin{array}{l}\text { self- } \\
\text { employed, } \\
\text { small } \\
\text { construction } \\
\text { company }\end{array}$ & $\begin{array}{l}\text { FE in } \\
\text { physical } \\
\text { education }\end{array}$ \\
\hline Sylwester & 40 & $\begin{array}{l}\text { large town } \\
\text { in western } \\
\text { Poland }\end{array}$ & 2004 & $\begin{array}{l}\text { married, } \\
\text { two } \\
\text { children }\end{array}$ & $\begin{array}{l}\text { factory } \\
\text { operative }\end{array}$ & postman & $\begin{array}{l}\text { FE technical } \\
\text { qualified } \\
\text { electrician }\end{array}$ \\
\hline Urszula & 34 & $\begin{array}{l}\text { village in } \\
\text { central- } \\
\text { west } \\
\text { Poland }\end{array}$ & 2007 & $\begin{array}{l}\text { married, } \\
\text { two } \\
\text { children }\end{array}$ & cleaner & $\begin{array}{l}\text { factory } \\
\text { worker }\end{array}$ & $\begin{array}{l}\text { general } \\
\text { secondary } \\
\text { ('A' levels) }\end{array}$ \\
\hline Waldemar & 48 & $\begin{array}{l}\text { village in } \\
\text { western } \\
\text { Poland }\end{array}$ & 2005 & $\begin{array}{l}\text { married, } \\
\text { six } \\
\text { children }\end{array}$ & care worker & $\begin{array}{l}\text { teacher in } \\
\text { secondary } \\
\text { school }\end{array}$ & $\begin{array}{l}\text { higher } \\
\text { (master's } \\
\text { degree) }\end{array}$ \\
\hline Witold & 31 & $\begin{array}{l}\text { medium- } \\
\text { size town } \\
\text { in southern } \\
\text { Poland }\end{array}$ & 2006 & $\begin{array}{l}\text { married, } \\
\text { two } \\
\text { children }\end{array}$ & cleaner & $\begin{array}{l}\text { ran own } \\
\text { peddling } \\
\text { business }\end{array}$ & $\begin{array}{l}\text { secondary } \\
\text { vocational }\end{array}$ \\
\hline
\end{tabular}

${ }^{a}$ Categories applied for size of (last) place of residence in Poland: rural area: village/farm of less than 2000 inhabitants; small town: 2000-14999 inhabitants; medium-town: 15 000-99999 inhabitants; large town: 100000-499999 inhabitants; big city: 500000 and over inhabitants. 